\title{
THE MEASUREMENT OF URINARY 8-HIDROXY-2'DEOXYGUANOSINE LEVEL WITH LIQUID CHROMATOGRAPHY-TANDEM MASS SPECTROMETRY METHOD IN PATIENTS WITH POL YCYSTIC OVARY SYNDROME
}

\author{
Seyda OZDEMIR ${ }^{1}$, Ozhan OZDEMIR ${ }^{2}$, Sevilay SEZER ${ }^{3}$, Oya TORUN $^{3}$, Huseyin Tugrul CELIK ${ }^{4}, \operatorname{Ramazan~SOYDAS}^{3}$, \\ Cemal ATALAY ${ }^{2}$, Muhittin SERDAR ${ }^{5}$, Metin YILDIRIMKAYA ${ }^{4}$
}

\author{
1 Department of Clinical Biochemistry, Diskapi Yildirim Beyazit Education and Research Hospital, Ankara \\ 2 Department of Obstetrics and Gynecology, Ankara Numune Education and Research Hospital, Ankara \\ 3 Department of Clinical Biochemistry, Ankara Numune Education and Research Hospital, Ankara \\ 4 Ankalab Laboratories, Clinical Biochemistry, Ankara \\ 5 Department of Clinical Biochemistry, Gülhane Military Medical Academy, Ankara
}

\begin{abstract}
SUMMARY
Objective: The measurement of urinary 8-hidroxy-2'deoxyguanosine (8-OHdG) level by liquid chromatographytandem mass (LC-MS/MS) method in order to determine whether there is an obvious oxidative deoxyribonucleic acid (DNA) damage in patients with polycystic ovary syndrome (PCOS) and its relationship with long term risks. Material and methods: Twenty-eight patients with PCOS diagnosis according to the criteria of 2003 Rotterdam Concensus Conference on PCOS were included in this study and twenty-seven healthy women were included as control group. After collecting first morning urine samples of patients and women in control group, the urinary 8-OHdG level were measured by LC-MS/MS method and the results were expressed as nmol/L. 8-OHdG/creatinine ratio (nmol/mol) was used to compensate the variation of all nucleoside concentration in urine. The patients with PCOS and the control group were compared in terms of the 8-OHdG/creatinine ratio.

Results: Statistically, there was not a significant difference between the patients with PCOS and the control group in terms of the 8-OHdG/creatinine ratio $(p=0.533)$.

Conclusion: According to our research, due to an increase of antioxidant and DNA repair capacity, the urinary 8OHdG/creatinine ratio as a determinant of oxidative stress in patients with PCOS was not different from the level analyzed in healthy women.
\end{abstract}

Key words: 8-OHdG, LC-MS/MS, oxidative stress, polycycstic ovary syndrome

Journal of Turkish Society of Obstetrics and Gynecology, (J Turk Soc Obstet Gynecol), 2014; Vol: 11, Issue: 1, Pages: 21-8

Address for Correspondence: Dr. Özhan Özdemir. Ankara Numune Eğitim ve Araştırma Hastanesi, Kadın Hastalıkları ve Doğum Kliniği, Ankara Phone: +90(0505) 2255078 e-mail: seyozi@hotmail.com

Received: 23 August 2013, revised: 10 November 2013, accepted: 11 November 2013, online publication: 14 November 2013 


\title{
LİKID KROMOTOGRAFİ-TANDEM KÜTLE SPEKTROMETRI YÖNTEMİ İLE POLIKIISTIK OVER SENDROMLU HASTALARDA İDRARDA 8-HİDROKSİ-2'-DEOKSIGGUANOZIN DÜZEYLERININ ÖLÇÜMÜ
}

\begin{abstract}
ÖZET
Amaç: Polikistik over sendromlu (PKOS) hastalarda oksidatif DNA hasarının gelişip gelişmediğinin ve uzun dönem risklerle ilişkisinin olup olmadığının tespiti adına idrar örneğinden LC-MS/MS yöntemi ile 8-OHdG seviyesinin ölçülmesi.

Gereç ve yöntemler: 2003 Rotterdam Concencus Conferance on PCOS (ESHRE-ASRM) kriterlerine göre PKOS tanısına uyan 28 hasta ve bu hastalarla benzer özellik gösteren sağllkl 27 kadın çalışmaya dahil edildi. Hasta ve kontrol grubundaki kadınların sabah ilk idrar örnekleri alınarak, LC/MS/MS yöntemi ile idrarda 8-OHdG düzeyi nmol/L cinsinden ölçüldü. İdrardaki tüm nükleozid konsantrasyonundaki varyasyonu kompanse etmek icin 8OHdG/kreatinin oranı (nmol/mol) kullanıldı. Hasta ve kontrol gruplar 8 OHdG / kreatinin oranı açısından karşılaştırıldı. Bulgular: PKOS hastaları ile kontrol grubu arasında idrar 8 OHdG / kreatinin (nmol/mol) oranı açısından istatistiksel olarak anlamlı fark saptanmamıştır $(p=0,533)$.

Sonuç: Çalısmamızda antioksidan ve DNA tamir kapasitesinin artmış olmasına bağll olarak oksidatif stres göstergesi olan idrarda 8 OHdG /kreatinin düzeyi PKOS'lu hastalarda sağllklı bireylerden farklı çıkmamıstır.
\end{abstract}

Anahtar kelimeler: 8-OHdG, LC-MS/MS, oksidatif stres, polikistik over sendromu

Türk Jinekoloji ve Obstetrik Derneği Dergisi, (J Turk Soc Obstet Gynecol), 2014; Cilt: 11, Sayl: 1, Sayfa: 21-8

\section{INTRODUCTION}

Free radicals are quite efficient chemical products that arise during metabolism in the body. The most important free radicals in biological systems are those derived from oxygen, and they are known as reactive oxygen species $(\mathrm{ROS})^{(1)}$. Free radicals produced in the body as a result of natural metabolism processes are normally removed by antioxidant systems breaking down radicals. However, the increase of reactive oxygen radicals due to several reasons and the inadequacy of antioxidant mechanisms are resulted in a series of pathological cases which are called as oxidative stress. It is a known fact that the imbalance between antioxidant defense and free radicals may lead to oxidative stress, and correspondingly to tissue damage(2).

Antioxidant systems play a significant role in the protection from harmful effects of free radicals. When this balance is broken in oxidative stress in favor of reactive oxygen species, deoxyribonucleic acid (DNA) goes into biological interaction with proteins, carbohydrates and lipids at cellular level, and consequently functional and structural damages occur in the cell(3).

Oxidative damage on DNA by ROS is accepted as the main cause and indicator of diseases caused by disruption in tissue function such as aging, cancer, cardiovascular diseases, immune system diseases, and degenerative diseases. This balance in women's reproductive health is also of high importance in various physiological and biochemical processes ranging from oocyte maturation to fertilization and from embryonic implantation to pregnancy $(4)$.

Reactive oxygen species (ROS) lead to formation of more than 20 base damage products in DNA. Among those bases, guanine is the one that goes easily and frequently into reaction ${ }^{(5)}$. $8-\mathrm{OHdG}$ is generated by the reaction of guanine in DNA with $\mathrm{OH}$ radical. 8OHdG is a quite sensitive marker of oxidative DNA damage. This damage is important because it is mutagenic and occurs easier than others. Thus, it is potentially a biomarker for cancer risk. DNA mutation is a critical step for carcinogenesis, and increased oxidative DNA lesion was observed on different types of tumors $(6)$.

Different methods and determinants are used in order to measure DNA damage in organism. Among 23 ROS-DNA base products, the most important and familiar one is 8-hidroxy- 2'deoxyguanosine (8-OHdG). For this reason, $8-\mathrm{OHdG}$ is used as a marker in detection of DNA damage( ${ }^{(7)}$.

Many researchers use urinary 8-OHdG measurement 
as a marker of 'whole body' oxidative DNA damage (8). 8-OHdG level also shows the balance between formation and reparation in DNA. The level of 8OHdG rises not only during oxidative DNA damage but also during the cases where reparation speed reduces (9).

In 1984, 8-OHdG was identified for the first time by Kasai and Nishimura as a marker of oxidative DNA damage ${ }^{(10)}$. Among the DNA constituents, guanine has the lowest ionization potential and is predictably, the most susceptible to oxidation(11). As a modified base, $8-\mathrm{OHdG}$ is one of the 20 oxidative base products on DNA by ROS, and it is a sensitive marker of DNA damage due to hydroxyl radical attack at the $\mathrm{C} 8$ of guanine. 8-OHdG is also one of the most frequently encountered oxidative DNA base damage products and has the highest mutagenic effects.

The reaction of $\mathrm{OH}$ radical with $\mathrm{C} 4, \mathrm{C} 5$, and $\mathrm{C} 8$ positions of guanine results in DNA radicals. $\mathrm{C} 8-\mathrm{OH}$, which is formed by the combination of $\mathrm{OH}$ radical and $\mathrm{C} 8$, turns into 8-OHGua by the loss of a single electron and a single proton ${ }^{(11)}$. 8-OHGua leads to an increase in the tendency to mutation by causing a transition from G-C into A-T (adenine-thymine) during DNA replication ${ }^{(12)}$. On this account, the measurement of 8-OHdG is accepted as the direct marker of oxidative DNA damage, and it is the most common method for the detection of oxidative DNA damage ${ }^{(13)}$.

Polycystic ovary syndrome (PCOS) is characterized by hyperandrogenemia, chronic anovulation, and menstrual dysfunction as well as being an endocrine disorder that can include morbidities such as hyperinsulinemia, insulin resistance, early-onset type 2 diabetes mellitus, dyslipidemia, cardiovascular disease and infertility(14).

In the literature, the negative effects of oxidative stress on various tissues and diseases have been negotiated so far; however, the number of the researches on PCOS is limited. Therefore, the aim of this study is to determine whether there is an oxidative DNA damage in PCOS or not by measuring 8-OHdG level.

\section{MATERIALS AND METHODS}

This prospective study was undertaken in Ankara Numune Training and Research Hospital with the approval of the local ethics committee. For this study,
28 patients with PCOS diagnosis according to the criteria of 2003 Rotterdam Concensus Conference on $\operatorname{PCOS}^{(14)}$ and 27 healthy volunteer women were selected among the cases in Ankara Numune Education \& Research Hospital, Obstetrics and Gynecology Department between June and September in 2010. The patients with diabetes mellitus, active lung disease, lung or kidney failure, cardiac failure, any systemic disease, hyperprolactinemia, and thyroid problems or symptoms of abnormal thyroid function as well as ones who have taken drugs like steroid or sex hormones in last six months due to various reasons, who were pregnant or lactating and drinking alcohol were not included in this study.

The identity information and ages of the patients were recorded and their body weights $(\mathrm{kg})$ and heights $(\mathrm{cm})$ were measured. Body mass index $\left(\mathrm{BMI}=\mathrm{kg} / \mathrm{m}^{2}\right)$ of each patient was also measured and recorded. The systemic and gynecologic examination and pelvic ultrasonography were all performed in obstetrics and gynecology clinic of our hospital.

The reference method for the measurement of urinary 8-OHdG level of liquid chromatography-tandem mass spectrometry (LC-MS/MS) method was used and measurement 'Ankalab' labs done. First morning urine samples of patients and women in control group were collected and kept in $10 \mathrm{~mL}$ red top vacutainer dry tubes at $-20^{\circ} \mathrm{C}$ until use. After the collection process, the samples were stored at room temperature and centrifuged at $1500 \mathrm{xg}$ for 5 minutes, and then the urinary 8-OHdG level was measured by LC-MS/MS $\operatorname{method}^{(15)}$.

\section{The measurement of urinary 8-OHdG level with $\mathrm{LC}$ - MS/MS method:}

The measurement of urinary 8-OHdG level with LCMS/MS method depends on quantitative measurement of $8-\mathrm{OHdG}$ following urine extraction. API 3200 tandem mass spectrometry is used in positive mode with Turbolon Spray electrospray (spray voltage $5 \mathrm{kV}$ and temperature $500^{\circ} \mathrm{C}$ ). Monitoring (MRM) mode was used for the detection of analytes. For each analyte, one MRM transition and internal standard were monitored. MRM mode 284/168 m/z was used for 8 OHdG, while mode $725.3 / 144.3 \mathrm{~m} / \mathrm{z}$ was used for internal standard (Vancomycin ).

Zorbax Eclipse XDB-C18 5 um, 4.6x150 mm column was used for separation process. For mobile phase, 
two different eluents were used. Mobile phase A contained deionized water with $0.15 \%$ formic acid, and mobile phase B contained methanol with $0.15 \%$ formic acid. The flow rate was $500 \mu \mathrm{L} / \mathrm{min}$ and $20 \mu \mathrm{L}$ was injected for each sample. For the elution of analytes from column, methanol gradient was used. Within first six minutes, $80 \%$ of mobile phase was adjusted to be isolated from A, and $20 \%$ from B. In next minute, the concentration of eluent $\mathrm{A}$ was increased to $70 \%$, and it was fixed during one minute. Each working time took seven minutes. First of all, urine samples were centrifuged at $1500 \mathrm{~g}$ for 5 minutes. The supernatant was worked. Then, to prepare samples, $1 \mathrm{~mL}$ of urine (calibrator, urine sample of control group and patient group) and $10 \mu \mathrm{L}$ of internal standard were added into Eppendorf tubes. Concentration of Vancomycin 0.05 $\mathrm{mg} / \mathrm{mL}$ was used as internal standard. After adding $100 \mu \mathrm{L}$ tricarboxylic acid (TCA), the samples were mixed with vortex during 30 seconds and the tubes were centrifuged at $13000 \mathrm{rpm}$ for 5 minutes. All the samples in the tubes were transferred to inserts and the inserts that were placed into vials were sent to the device for injection. The results of $8-\mathrm{OHdG}$ was expressed as nmol/L.

\section{The standards of 8-OHdG:}

8 -OHdG standard curve and chromatograms related to $0,62.5$ and $250 \mathrm{nmol}$ of $8-\mathrm{OHdG}$ are illustrated in the figure of $1,2,3,4$.

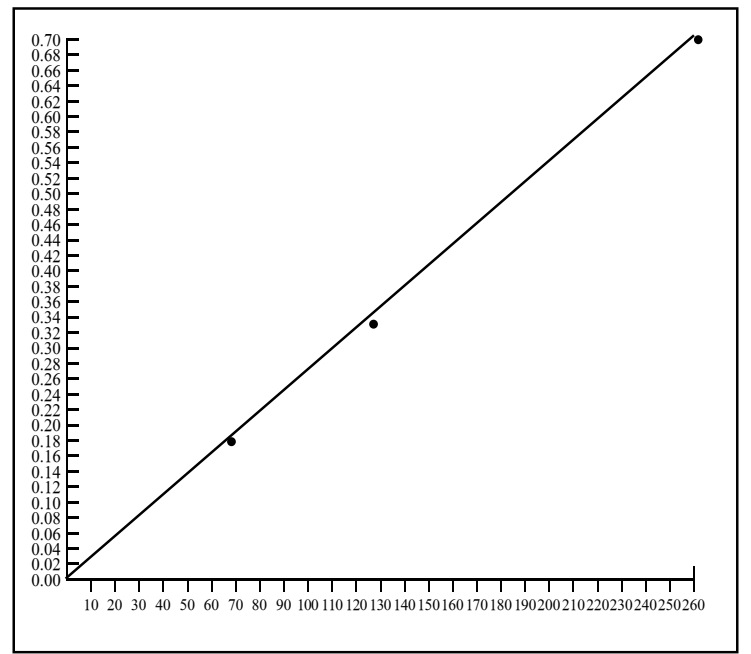

Figure 1: 8-OHdG standard curve.

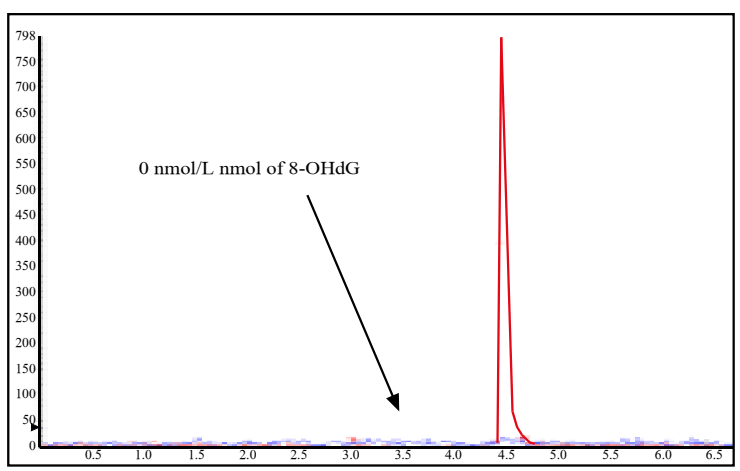

Figure 2: Chromatogram of $0 \mathrm{nmol} 8-\mathrm{OHdG}$ standard.

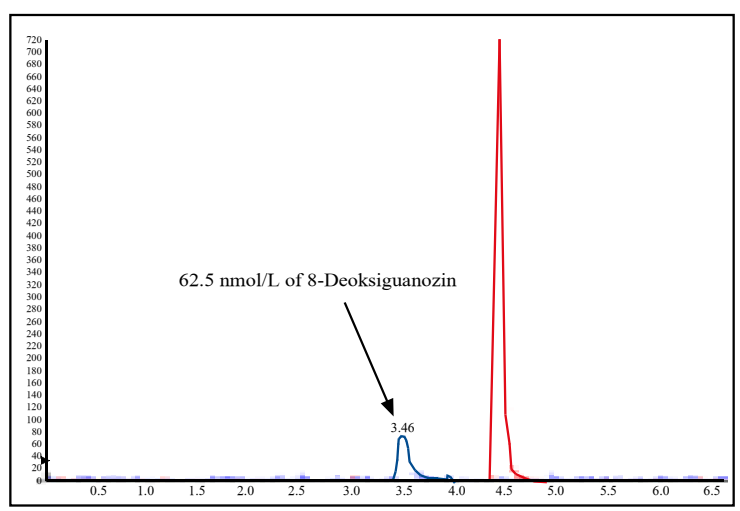

Figure 3: Chromatogram of $62.5 \mathrm{nmol} \mathrm{8-OHdG} \mathrm{standard.}$

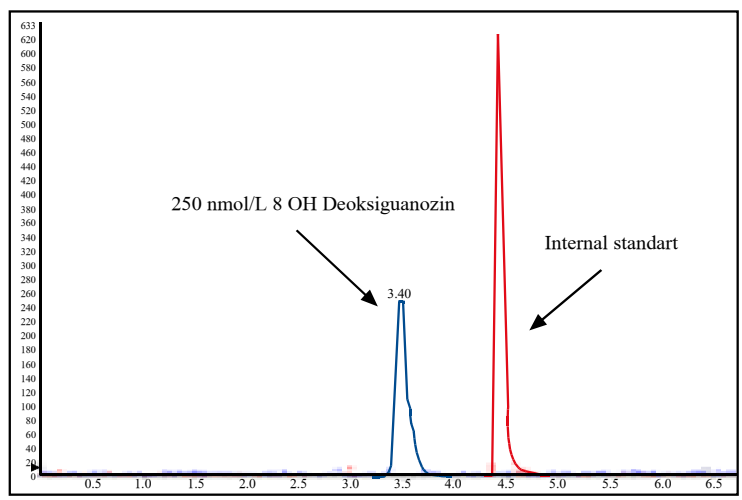

Figure 4: Chromatogram of $250 \mathrm{nmol} \mathrm{8-OHdG} \mathrm{standard.}$

\section{8-OHdG / creatinine ratio ( $\mathrm{nmol} / \mathrm{mol})$ :}

$8-\mathrm{OHdG} / \mathrm{creatinine}$ ratio $(\mathrm{nmol} / \mathrm{mol})$ was used to compensate the variation of all nucleoside concentration in urine.

\section{Method of measuring urinary creatinine:}

Abbott Architect device was used for the measurements. The method of measuring creatinine is based on the reaction between creatinine and sodium picrate. At an alkaline $\mathrm{pH}$, creatinine in the sample reacts with picrate to form a creatinine-picrate complex. The rate of increase in absorbance at $500 \mathrm{~nm}$ due to the formation of this complex is directly proportional to the concentration of creatinine in the sample. The results were introduced as $\mathrm{mg} / \mathrm{dL}$ and they were converted to $\mathrm{mol} / \mathrm{L}$. 


\section{Statistical analysis}

The statistical analysis of data was made analyzed using SPSS version 16.0 for Windows. As descriptive statistics, mean \pm standard deviation was used. Kolmogorov-Smirnov Z Test was conducted to analyze whether there was a normal distribution of constant variables. The statistical difference between groups in terms of concerning variables was measured by Independent Samples $\mathrm{T}$ Test in parameters with homogenous distribution while Mann-Whitney-U Test was used in parameters with non-homogenous distribution. Correlation analysis was performed to examine the relationships between urinary $8-\mathrm{OHdG}$ and BMI. The error rate was estimated as a $=0.05$.

\section{RESULTS}

Mean ages and mean body mass index of 28 patients with PCOS and 27 patients in control group were shown in Table I. No statistical difference concerning age and BMI was noted when the groups were compared according to demographic features ( $p>0.05$ ). Those 28 patients with PCOS diagnosis were divided into two groups as ones having obesity (BMI $\geq 27$ $\mathrm{kg} / \mathrm{m}^{2}$ ) and without obesity. The obesity limit was determined as $27 \mathrm{~kg} / \mathrm{m}^{2}$ due to reduced insulin sensitivity $(16)$.

Table I: Demographic features of groups.

\begin{tabular}{llll}
\hline & $\begin{array}{l}\text { Age } \\
(\text { Mean } \pm \text { SD) }\end{array}$ & $\begin{array}{l}\text { BMI } \\
(\text { Mean } \pm \text { SD) }\end{array}$ & p \\
\hline Control $(\mathrm{n}=27)$ & $26,4 \pm 6$ & $21,7 \pm 3$ & $\mathrm{p}>0.05$ \\
PCOS patients $(\mathrm{n}=28)$ & $23,3 \pm 5,6$ & $24,6 \pm 3,8$ & $\mathrm{p}>0.05$ \\
\hline
\end{tabular}

The statistical analysis showed that there was not a significant difference between the patients with PCOS and the control group in terms of the $8-\mathrm{OHdG} /$ creatinine ratio $(p=0.533)$ (Table II).

Table II: The comparison of urinary 8-OHdG/creatinine ratio (nmol/mol) between patients with PCOS and control group.

\begin{tabular}{llll}
\hline & Group & Mean \pm SEM & p \\
\hline $\begin{array}{l}\text { Urinary 8-OHdG/ } \\
\text { creatinine (nmol } / \mathrm{mol})\end{array}$ & PCOS $(\mathrm{n}=28)$ & $19.45 \pm 5.4$ & 0.533 \\
& Control $(\mathrm{n}=27)$ & $10.08 \pm 2.05$ & \\
\hline
\end{tabular}

Statistically, no significant difference was found when 8-OHdG/creatinine ratios of PCOS patients with BMI $<27$ and $\mathrm{BMI} \geq 27$ was compared control group of BMI $<27$ and $\mathrm{BMI} \geq 27$ but a negative correlation ( $\mathrm{r}=-0.59$, $\mathrm{p}<0.05$ ) was found between $8-\mathrm{OHdG} /$ creatinine ratio and BMI in PCOS patients (Table III).

Statistically, no significant difference was found when $8-\mathrm{OHdG} /$ creatinine ratios of PCOS patients with smokers and non-smokers was compared control group of smokers and non-smokers but a positive correlation $(\mathrm{r}=0.42, \mathrm{p}<0.05)$ was found between $8-\mathrm{OHdG} /$ creatinine ratio and smoke in PCOS patients (Table IV).

\section{DISCUSSION}

All living organisms are exposed to oxidant agents deriving from both endogenous and exogenous sources during their lifetime, and correspondingly they produce free radicals ${ }^{(17)}$. These free radicals are neutralized with antioxidant defense mechanisms which are enzymatic

Table III: The comparison of 8-OHdG/creatinine (nmol/mol) ratio of groups concerning BMI.

\begin{tabular}{lll}
\hline & $\begin{array}{l}\text { 8-OHdG/creatinine } \\
\text { (Mean } \pm \text { SEM) }\end{array}$ & $\begin{array}{l}\text { Coefficient of variations } \\
(\%)\end{array}$ \\
\hline PCOS patients with BMI $\geq 27 \mathrm{~kg} / \mathrm{m}^{2}(\mathrm{n}=8)$ & $30.38 \pm 11.4$ & 38.51 \\
Control with BMI $\geq 27 \mathrm{~kg} / \mathrm{m}^{2}(\mathrm{n}=3)$ & $17.2 \pm 7.6$ & 44.18 \\
PCOS patients with BMI $<27 \mathrm{~kg} / \mathrm{m}^{2}(\mathrm{n}=20)$ & $15.08 \pm 6.03$ & 39.98 \\
Control with BMI $<27 \mathrm{~kg} / \mathrm{m}^{2}(\mathrm{n}=24)$ & $9.1 \pm 2.1$ & 23.07 \\
\hline
\end{tabular}

Table IV: The relationship between 8-OHdG/creatinine (nmol/mol) ratio of patients with PCOS and cigarette use \& BMI.

\begin{tabular}{lll}
\hline & $\begin{array}{l}\text { 8-OHdG/creatinine } \\
\text { (Mean } \pm \text { SEM) }\end{array}$ & $\begin{array}{l}\text { Coefficient of variations } \\
\text { (\%) }\end{array}$ \\
\hline PCOS patients with non smokers $(\mathrm{n}=20)$ & $26.5 \pm 14.2$ & 53.58 \\
PCOS patients with smokers $(\mathrm{n}=8)$ & $16.61 \pm 5.29$ & 31.84 \\
PCOS patients with BMI $<27 \mathrm{~kg} / \mathrm{m} 2(\mathrm{n}=20)$ & $15.08 \pm 6.03$ & 39.98 \\
PCOS patients with BMI $\geq 27 \mathrm{~kg} / \mathrm{m} 2(\mathrm{n}=8)$ & $30.38 \pm 11.4$ & 37.52 \\
\hline
\end{tabular}


or non-enzymatic. When free radicals increase beyond sufficiency of this defense mechanism, they cause cell injuries by attacking on biological macromolecules such as lipids, proteins, and $\mathrm{DNA}^{(2)}$.

All changes that occur on molecular integrity of genetic material due to the effect of endogenous and exogenous factors are called "DNA damage". The integrity of genomic DNA is constantly under threat because of environmental factors. DNA may undergo some endogenous changes during cellular events such as DNA replication or DNA recombination(18). DNA damage is relatively a common event that may lead to mutation, cancer, aging, and subsequently to cell death. Throughout the life, DNA is constantly exposed to changes by cellular metabolites (ROS) and exogenous agents. Depending on this issue, those changes may cause cell deaths in single-celled organisms as well as degeneration or aging in multi-celled organisms ${ }^{(3)}$.

Apart from $8-\mathrm{OHdG}$, there are many base damage products in DNA. 8 hydroxyadenine, 8 hydroxyguanine and 7 methyl - 8 hydroxyguanine are some of those products. A few of these (like 8 hydroxyadenine) may arise in whole or in part from diet. Especially during the cooking of foods, DNA may undergo oxidation and oxidized bases may be absorbed after hydrolysis of DNA in the gastrointestinal tract. However, urinary 8 -OHdG is not affected by diet, because, under normal conditions, nucleosides are not absorbed from the gastrointestinal system $^{(9)}$. Therefore, as a difference, we made our research in urine and we tried to determine the formation level of endogenous 8-OHdG in PCOS without being affected by external input. Relatively, we have not found any research on $8-\mathrm{OHdG}$ as a biomarker of DNA damage in urine although there are many studies measuring 8-OHdG level in serum and plasma as oxidative stress marker in patients with PCOS.

PCOS is one of the most frequent endocrinological diseases observed in women with proven infertility. PCOS, which is the most common reason of chronic anovulatory infertility, is of high importance nowadays in terms of women's health due to having long- term health risks such as endometrial carcinoma, atherosclerosis, cardiovascular disease, dyslipidemia, and type- 2 diabetes mellitus as multisystemic reproductive-metabolic syndrome. Recently, some studies also have shown that PCOS is a risk factor for ovarian and breast cancer ${ }^{(19)}$.
Oxidative stress has a negative effect in reproductive life of women ${ }^{(4)}$. ROS has many physiological effects ranging from oocyte maturation to fertility, as well as embryonic development and pregnancy. The balance of oxidative stress in patients with PCOS was analyzed in studies with methods which are not relatively specific such as malondialdehyde (MDA) and glycolysis products. In many of these studies, oxidative stress level in patients with PCOS was observed to increase (20).

8 -OHdG measurement is one of the most reliable methods for the analysis of oxidative stress and specifically it points out DNA damage related to oxidative stress. 8-OHdG is studied with different methods such as high-performance liquid chromatography (HPLC), enzyme-linked immunosorbent assay (ELISA), tandem-mass spectrometry, and immune histochemical techniques. Although these methods have mutual advantages and disadvantages, the most frequent methods are HPLC and electrochemical detector. However, each laboratory working on 8-OHdG depends on different levels of 8OHdG. So far, common quality control method for 8$\mathrm{OHdG}$ has not been found, and no standardization for 8-OHdG measurement has existed yet. For this reason, striking differences may occur between laboratories and their methods ${ }^{(15)}$.

In our study, we used liquid chromatography/mass spectrophotometry (LC-MS/MS) method so as to measure 8-OHdG levels in urine samples of patients with PCOS. The level of $8-\mathrm{OHdG} /$ creatinine ratio in urine of patients with PCOS was expected to be higher than control group due to increased DNA damage related to reactive oxygen radicals. However, we have not found any statistical difference between PCOS and control group. This result may depend on two reasons. The first reason shows that oxidative DNA damage in patients with PCOS was treated or antioxidant mechanisms were efficient at the same rate. In a study in which 8-OHdG was used in plasma as a marker of oxidative DNA damage, no difference was noted between healthy women and patients with PCOS, and this is because of increased endogenous DNA treatment in women with $\operatorname{PCOS}{ }^{(13)}$. In another study, serum 8-OHdG levels in PCOS group were found to be markedly lower when compared to control group ${ }^{(21)}$. According to second reason, high ROS levels increase antioxidant enzyme production in patients with PCOS, and concerning this issue oxidative 
stress may undergo pressure. Some studies show that major antioxidant enzymes are found to be apparently increased in patients with PCOS when compared to healthy women ${ }^{(22)}$.

In a study analyzing protein in serum depending on MDA in patients with PCOS and without PCOS, the level of serum protein-MDA was found to be apparently high in patient group. Some studies put forward that the reason of increased oxidative stress may depend on metabolic and reproductive anomalies related to $\operatorname{PCOS}(23)$.

Cigarette smoke contains a mixture of free radicals. It is quite possible that smokers are under threat of increasing cancer risk due to serious effects of free radicals. Smoke increases the level of $8-\mathrm{OHdG}$ in human urine and DNA of white blood cells(24). According to Loft and his colleagues, urinary 8-OHdG level is $50 \%$ higher in smokers than in healthy ones (25). Also, it was determined that 8-OHdG level increases in parallel with the number of cigarettes smoked daily ${ }^{(24)}$. Many reasons may be available for increased 8-OHdG level in smokers. That the cellular respiration rate is $10-15 \%$ higher than non-smokers leads to formation of free radicals and DNA damage increases following antioxidant consumption ${ }^{(25)}$. The observation of nearly seven-times more differences in 8-OHdG levels obtained from leukocytes DNA of nonsmokers leads to idea that genetic factors and lifestyle may have effect on the increase of 8-OHdG level. According to some studies, age factor, smoking, and working hours in jobs carrying threats of cancer risk goes parallel with the increase of urinary $8-\mathrm{OHdG}$ level(26). In our study, we have found a positive $(r=$ $0.42, \mathrm{p}<0.05$ ) difference between $8-\mathrm{OHdG} /$ creatinine ratio and smoke in PCOS patients but we have not found any significant difference between PCOS patients with smokers and non-smokers in terms of 8$\mathrm{OHdG} /$ creatinine ratio. This result may stem from the ages of patients included in the study as well as the duration of cigarette use and number of cigarettes smoked daily.

Various studies illustrate the relationship between 8OHdG and BMI and people with high body mass index (BMI) have lower 8-OHdG level than slim people(27). The study conducted by Loft and his colleagues shows that urinary 8-OHdG extraction level decreases while body mass index increases. The possible reason for high level of $8-\mathrm{OHdG}$ extraction in men (29\% higher) and slim people is ascribed to increasing ROS production related to metabolism ${ }^{(25)}$. In our study, we have have found a negative correlation $(r=-0.59, p$ $=0.034$ ) between $8-\mathrm{OHdG} /$ creatinine ratio and $\mathrm{BMI}$ in PCOS patients but we have not found any significant difference between PCOS patients with $\mathrm{BMI} \geq 27$ and BMI $<27$ in terms of $8-\mathrm{OHdG} /$ creatinine ratio.

As a consequence, due to an increase of antioxidant and DNA repair capacity, the urinary $8-\mathrm{OHdG} /$ creatinine ratio as a determinant of oxidative stress in patients with PCOS is not different from the level analyzed in healthy women. However, the urinary 8$\mathrm{OHdG} /$ creatinine ratio can be analyzed in a larger group of patients and can be associated with prospective studies about PCOS.

\section{REFERENCES}

1. Gulbahar O. The mechanism, significance and relationship with aging of protein oxidation. Turkish Journal of Geriatrics, 2007;10(1):43-8.

2. Urso ML, Clarkson PM. Oxidative stress, exercise and antioxidant supplementation. Toxicology 2003;189(1-2):4154.

3. Sancar A, Lindsey-Boltz LA, Unsal-Kacmaz K, Linn S. Molecular mechanisms of mammalian DNA repair and the damage checkpoints. Annu Rev Biochem 2004;73:39-85.

4. Agarwal A, Gupta S, Sharma S. Role of oxidative stress in female reproduction. Reprod Biol Endocrinol 2005;3:28.

5. De Martinis BS, De Lourdes Pires Bianchi M. Methodology for urinary 8-hydroxy-2'-deoxyguanosine analysis by hplc with electrochemical detection. Pharmacol Res 2002;46(2): 129-31.

6. McDorman KS, Pachkowski BF, Nakamura J, Wolf DC, Swenberg JA . Oxidative DNA damage from potassium bromate exposure in long-evans rats is not enhanced by a mixture of drinking water disinfection by-products. Chem Biol Interact 2005;152(2-3):107-17.

7. Yokus B, Cakır DU. İn vivo oksidatif DNA hasarı biyomarkerı; 8- hydroxy-2'-deoxyguanosine. T Klin J Med Sci 2002;22:53543.

8. Cheng KC, Cahill DS, Kasai H, Nishimura S, Loeb LA. 8Hydroxyguanine, an abundant form of oxidative DNAdamage, causes GfT and AfC substitutions. J Biol Chem 1992;267(1): 166-72.

9. Hamurcu Z, Bayram F, Kahriman G, Dönmez-Altuntas H, Baskol G. Micronucleus frequency in lymphocytes and 8- 
hydroxydeoxyguanosine level in plasma of women with polycystic ovary syndrome. Gynecol Endocrinol 2010;26(8): 590-5.

10. Falcon T, Hurd W, Clinical Reproductive Medicine and Surgery, Mosby Inc. Elsevier, 2007.

11. Rotterdam ESHRE/ASRM-Sponsored PCOS Consensus Workshop Group. Revised 2003 consensus on diagnostic criteria and long-term health risks related to polycystic ovary syndrome. Fertil Steril 2004;81(1):19-25.

12. Jaffe M. Ueber den Niederschlag, welcen Pikrinsaure in normalem Harn erzegut und uber eine neue Reaction des Kreatinins. Hoppe Seylers Z Physiol Chem 1886;10:391-400.

13. Campell PJ, Gerich JE. Impact of obesity on insulin actionin volunteers with normal glucose tolerance: demonstration of a threshold for the adverse effect of obesity. J Clin Endocrinol Metab 1990;70(4):1114-8.

14. Halliwell B. Free radicals, antioxidants and human disease: curiosity, cause or consequence? Lancet 1994;344(8924):7214.

15. Kulaksız G, Sancar A. Nucleotide excision repair and cancer. Turk J Biochem 2007;32(3):104-11.

16. Mori T, Tano K, Takimoto K, Utsumi H. Formation of 8hydroxyguanine and 2,6-diamino-4-hydroxy-5-formamidopyrimidine in DNA by riboflavin mediated photosensitization. Biochem Biophys Res Commun 1998;242(1):98-101.

17. Valko M, Rhodes CJ, Moncol J, Izakovic M, Mazur M. Free radicals, metals and antioxidants in oxidative stress-induced cancer. Chem Biol Interact 2006;160(1):1-40.

18. Loft S, Fischer-Nielsen A, Jeding IB, Vistisen K, Poulsen HE. 8 hydroxydeoxyguanosine as a urinary marker of oxidative DNA damage. J Toxicol Environ Health 1993;40(2-3):391404

19. Halliwell B. Oxygen and nitrogen are pro-carcinogens. Damage to DNA by reactive oxygen, chlorine and nitrogen species: Measurement, mechanism and the effects of nutrition. Mutat Res 1999;443(1-2):37-52.

20. Gadducci A, Gargini A, Palla E, Fanucchi A, Genazzani AR. Polycystic ovary syndrome and gynecological cancers: is there a link? Gynecol Endocrinol 2005;20(4):200-8.
21. Fenkci V, Fenkci S, Yilmazer M, Serteser M. Decreased total antioxidant status and increased oxidative stress in women with polycystic ovary syndrome may contribute to the risk of cardiovascular disease. Fertil Steril 2003;80(1):123-7.

22. European Standart Committee on Oxidative DNA Damage. Interlaboratory validation of procedures for measuring 8-oxo7,8-dihydroguanine/8-oxo-7,8-dihydro-2'-deoxyguanosine in DNA. Free Radic Res 2002;36(3):239-45.

23. Sova H, Morin-Papunen L, Puistola U, Karihtala P. Distinctively low levels of serum 8-hydroxydeoxyguanosine in women with polycystic ovary syndrome. Fertil Steril 2010; 94(7):2670-3.

24. Atiomo W, Khalid S, Parameshweran S, Houda M, Layfield R. Proteomic biomarkers for the diagnosis and risk stratification of polycystic ovary syndrome: a systematic review. BJOG 2009;116(2):137-43.

25. Palacio JR, Iborra A, Ulcova-Gallova Z, Badia R, Martínez P. The presence of antibodies to oxidative modified proteins in serum from polycystic ovary syndrome patients. Clin Exp Immunol 2006;144(2):217-22.

26. Kiyosawa H, Suko M, Okudaira H, Murata K, Miyamoto T, Chung $\mathrm{MH}$, et al. Cigarette smoking induces formation of $8 \mathrm{OhdG}$, one of the oxidative DNA damage, in human peripheral leukocytes. Free Radic Res Commun 1990;11(1-3):23-7.

27. Loft S, Vistisen K, Ewertz M, Tjonneland A, Overvad K, Poulsen HE. Oxidative DNA damage estimated by 8 hydroxydeoxyguanosine excretion in humans: influence of smoking, gender and body mass index. Carsinogenesis 1992; 13(12):2241-7.

28. Lagorio S, Tagesson C, Forastiere F, Iavarone I, Axelson O, Carere A. Exposure to benzen and urinary concentrations of 8-hydroxydeoxyguanosine, a biological marker of oxidative damage to DNA. Occup Environ Med 1994;51(11):739-43.

29. Kasai H, Iwamoto-Tanaka N, Miyamoto T, Kawanami K, Kawanami S, Kido R, et al. Life style and urinary 8hydroxydeoxyguanosine, a marker of oxidative DNA damage: effects of exercise, working conditions, meat intake, body mass index, and smoking. Jpn J Cancer Res 2001;92(1):915 . 